\title{
Attitudes towards Information Privacy amongst Black South African Generation Y Students: A Study of Loyalty Cards
}

\author{
Ufuoma Akpojivi, PhD. \\ Postdoctoral Fellow, North West University, Vaal Triangle Campus, South Africa. \\ Email: fuoteg@yahoo.com
}

\section{Doi:10.5901/mjss.2013.v4n3p647}

\section{Abstract}

Aim: In this era of globalisation characterised with rapid spread and usage of Information Communication Technology (ICT) and the capacity to store personal information, the issue of information privacy is becoming an increasing concern. In this study, the attitude of Black South African Generation Y students towards information privacy in relation to loyalty card usage was examined. Method: A total of 400 questionnaires were administered to participating students from two higher education institutions including the North West University Vaal Triangle Campus, and the Vaal University of Technology. The awareness and knowledge of Generation Y students on data collection practices with loyalty cards, and the relationship between information privacy concerns and purchase behaviour with regard to loyalty card usage was also examined. Results and conclusion: Using Pearson's correlation analysis, reliability test and preliminary data analysis, it was revealed that Black Generation Y students were concerned with their information privacy in relation to loyalty cards, and this significantly affected their attitude towards loyalty card usage. The ability to control their data usage, i.e. knowledge of what their data is being used for by business organisations also positively influenced their perception towards loyalty cards as Generation Y students were irritated by unsolicited marketing offers from business organisations.

Keywords: Privacy, Consumer Protection, Loyalty Cards, Generation Y, South Africa.

\section{Introduction}

In this competitive global economy, the sustainability and growth of any business is dependent on informationinformation about their business environment, clients, customers and their competitors. According to Collier (1995 p.41), 'knowledge is power' in the business world, and so it is a valuable tool for decision making by business managers (Culnan, 1993 p.342). Consequently, data collection from customers is on the increase. The data collected are used to facilitate increase in sales, build on customer service relationship and establish business relationships between the business organisations and customers (ibid; Argandona, 2003). Moreover, because it is possible to collect and store a vast amount of information using Information Communication Technology (ICT) (Culnan \& Armstrong, 1999), the use of ICT in data collection by business organisations has been on the rise in the last decade (Graeff \& Harmon, 2002). Most business organisations seeking information about their customers tap into the potentials of these information communication technologies (Jarvenpaa \& Staples, 2001), which is considered by many a vital strategy for a successful organisation in an increasingly competitive business environment (Culnan \& Armstrong, 1999). To this end, businesses have initiated different programmes or reward schemes such as loyalty cards, reward club cards, discount/point programme that are all geared towards collecting valuable information about their customers. These programmes are able to record all transactions i.e. 'specific items purchased and the time of day of the purchase' (Graeff \& Harmon, 2002 p. 302). Consequently, the information gathered through these various reward schemes and loyalty programmes are used by businesses to target potential buyers and develop business strategies (Foxman \& Kilcoyne, 1993).

Scholars are increasingly concerned about the amount of consumer information in possession by retailers, marketers, amongst others. This is because business organisations are yet to state what they do with the information being collected and how they manage and prevent such information from getting into wrong hands. According to Zurawski (2011 p.509), the practice of daily collection of purchasing information from customers using loyalty cards and other reward schemes raises the question of 'why such data is collected in the first place'. This has become even more 
worrisome as vulnerable people ${ }^{1}$ are targeted by these business organisations. Although the growing concern for information privacy in relation to the application of information communication technologies in societies is not a new phenomenon (see Clarke, 1988), there are still very few studies in South Africa which examine the issue of information privacy with regard to vulnerable people (e.g. the Black Generation Y students). Most studies on information privacy are from the European and American perspectives, while the few literatures that examine Generation $Y$ are from the economic gains perspective (see Plessis, 2009), thus neglecting privacy issues associated with such economic transactions.

On the other hand, there has been a steady increase in the emancipation of black South Africans (who are considered as the 'fastest growing market' in South Africa with a spending power of approximately R200 billion (UCT Unilever Institute of Strategic Marketing, 2008)) following political and economic freedom in South Africa at the end of Apartheid in 1994 (Venter, 2010). The black Generation Y2 students which make up 33\% of South Africa's population are regarded as the future 'Black Diamonds' (Statistic South Africa, 2011; see also Smith, 2010) because they are better educated and are expected to earn higher incomes (Hawkins et al., 2007 cited in Plessis et al., 2009). Consequently, this group is targeted by business organisations through the use of different data collection techniques (loyalty cards, points/bonus programmes). This has raised many questions on how much information is needed by these businesses, how the information is used and to what purpose(s).

This study was therefore done to examine the attitude of Black South African Generation Y Students toward Information Privacy with regard to the use of loyalty cards. The following research questions were considered:

$>$ What is the attitude of Black South African Generation Y Students toward Information Privacy?

$>$ What factors influence the attitudes of Black South African Generation Y Students toward Information Privacy?

$>$ Do prior knowledge of Information Privacy influence their attitudes toward Information Privacy?

> What Factors motivate Black South African Generation Y Students to have Loyalty Cards? And do these factors influence their perception of Information Privacy?

\section{What is Information Privacy?}

There has been a rising number of literature on information privacy (Smith et al., 1996). Different scholars however, conceptualise information privacy from different theoretical perspectives. It is therefore difficult to conceptualise information privacy as it has no universally acceptable definition (Goodwin, 1991). Simitis argues that the 'more the need for a convincing definition of privacy based on criteria free of inconsistencies has been stressed, the more abstract the language has grown' (1987 p. 708). Dinev and Hart have also stated that 'every theoretical perspective involving privacy accounts for its complexity, given its multidimensional elastic, contextually dependent and dynamic nature, and the dichotomy between the individual and others' (2006a p. 8).

Nonetheless the need to understand the 'nature and impact' of information privacy (Dinev \& Hart, 2006a p. 7) cannot be overemphasised. Information privacy is predominately viewed from the legal perspective i.e. privacy is usually considered as a right (Dinev \& Hart, 2006; Miyazaki \& Fernandez, 2000). According to Goodwin (1991), information privacy is a fundamental consumer right. Collier (1995 p. 5) added that 'privacy is a value which underpins human dignity and other key values such as freedom of association and freedom of speech'. Similarly, Pollach posited that information privacy is an 'element of human dignity' (2005 p. 222). From the statements above, it can be argued that information privacy is a natural human right and that personal information belonging to an individual should be protected (Solove, 2001). Nevertheless, the idea of information privacy is multi-dimensional as rights could be ethical, social or legal (Dinev \& Hart, 2006a).

Information privacy as a right has become a major policy issue (Goodwin, 1991). Countries have developed laws or policies as instruments to protect information privacy. For instance, the United States and the European Union have both formulated privacy laws that are aimed at protecting individuals' privacy from abuse by the state and other organisations (see Culnan, 1993). There are two dimensions to information privacy as a right. These include the ability of individuals to control unwanted information or personal intrusion and the ability to control information about himself or

\footnotetext{
1 It is difficult to conceptualise vulnerable people as it means different things to different people. In this study, I am associating vulnerable people to mean people who do not know that they are being directly and indirectly targeted by business organisation to purchase goods due to their rise in economic power.

${ }^{2}$ The conceptualisation of Generation Y is difficult, as different scholars conceptualise Generation Y based on different criteria, i.e. age (period of birth), technological innovations etc. (see Nimon, 2007; Weiler, 2005). In this study, Generation Y is conceptualised as students born between 1986-2005. This is further discussed in the paper.
} 
herself (Goodwin, 1991). Opinions that stem from these dimensions are that information privacy means the right to be left alone i.e. free from intrusion (Brandeis and Warren, 1890; Haag, 1971). Not only is this position myopic, seeing that no one can live in isolation in a society, it further raises the issue of separating public and private interests which is often difficult (Introna \& Pouloudi, 1999). Also, the idea of non-intrusion equates privacy with liberty, and although both concepts are similar, they are distinct in their applications (Tavani, 2007). This distinction borders on the question of when an individual's information should be kept private or made public.

The desire to control unwanted information and individual information lays the philosophical background to information privacy as a right. This is because when people 'provide their personal information, they have the right to know why the information is being collected, its expected uses, the steps that will be taken to protect its confidentiality, integrity and quality, the consequences of providing or withholding information and any means of redress available to them' (Culnan \& Armstrong, 1999 p. 107). They also have the right to control how their personal information will subsequently be used by objecting to uses not original intended (ibid). Individuals always desire to control information about themselves and when this is not possible privacy concerns are raised. Fusilier and Hoyer (1980), buttressed this further by stating that people who think that they can exercise control over their details are positively disposed to information privacy (cited in Culnan, 1993).

However, the idea of control, which forms the basis of information privacy as a right is relative, as the ability of individuals to control their information is dependent on social or cultural factors which vary from context to context (Johnson, 1989 cited in ibid). Rule (2004), argued that not everyone enjoys the right to control their personal details, and even when they do, they do not actually live a private life. According to him, this highlights the non-intuitive implications of conceptualising privacy in this way. Mill while substantiating further argued that since individuals live in a society, society has jurisdiction over the affairs of individuals and their conduct, hence it is difficult to control their information from being in the hands of others (1869 \{1974\}). If individuals are left alone without being monitored or if relevant authorities do not have details about individuals, these individuals could cause harm and threaten the very existence of society itself (Kendall, 1966; Mill, 1869\{1974\}).

Furthermore, it is practically impossible for individuals to withhold information about themselves in this technological era. This is because the activities of an individual whether public (shopping habits etc.) or private (government use of personal information for security reasons) are being monitored (Graeff \& Harmon, 2002). This brings to bear the ethical dimension of information privacy as a right. Most individuals provide their details to business organisations in exchange for 'tangible or intangible benefits' (Milne \& Gordon, 1993; see also Youn, 2009). As Hine puts it, 'to participate fully in today's consumer society, people must reveal some personal information' (1998 p. 253). This willingness to disclose information by consumers in order to gain certain benefits creates a 'thin line between the need to disclose information for the benefit of some individuals and the need to safeguard the privacy of some individuals by not disclosing this information' (Introna \& Pouloudi, 1999 p. 27-28). Information provided by consumers may be used by businesses to identify ways of meeting consumer needs and improving consumer satisfaction.

This raises the questions of whether or not business organisations violate the privacy of consumers by using the collected information for other purposes (Simitis, 1987) and who owns the information provided by the consumers during business transactions (see Miyazaki \& Fernandez, 2000). Some scholars like Milne and Gordon (1993 p. 208) have argued that there are no ethical implications with such usage of consumer information because such information could be considered the property of the business organisations 'to do with what they wish'. Phelps et al. (2000), also posited that the usage of data-outside the original purpose- from the consumer does not pose or cause harm to them, but will enable the business to meet the preferences/needs and provide incentives to the consumer (Staten \& Cate, 2003). Other scholars like Solove, have argued that based on the natural right concept, the information provided by consumers belong to the consumers and not the businesses and should not be used for other purposes without first seeking approval from the consumers (2001 p. 1447). Pollach (2005 p. 221), on the other hand, argued that 'neither the consumers nor businesses have absolute proprietary rights to the information that is exchanged in commercial transactions'. He however stated that based on the theory of informed consent, the consumer should be informed of the businesses' desire to use consumer information for marketing purposes beyond the reason why the consumers provided such information (Faden \& Beauchamp, 1986 cited in Pollach, 2005 p. 222).

The above argument reinstates the need for information control by the consumer (see Pretschner et al., 2006; Pollach, 2005). The indiscriminate use of consumer information by businesses places the consumer at a disadvantage as they are mainly considered and treated as 'means not an ends' because their right to 'autonomy is not recognised' (Foxman \& Kilcoyne, 1993 p. 109). To Solove (2001), consumers should be told what the information they provide will be used for and what end. Besides, consumers are stakeholders in the marketing industry and should have knowledge of/be 
able to control the way their details are used (Foxman \& Kilcoyne, 1993). Thus, there is need for businesses to protect the privacy of the consumer or strike a balance between data collection for marketing purposes and protecting the consumer (Solove, 2001 p. 1447) as this is the main cause of privacy tension between consumers and businesses during transactions (Culnan \& Armstrong, 1999).

This idea of consumer knowledge and control by Foxman and Kilcoyne (1993) further leads to the philosophical perspective of information privacy. Theorists who support the philosophical perspective of information privacy argue that the centrality of this perspective is centred on the ability of individuals to control information about themselves based on their knowledge (Wasserstrom, 1978, cited in Foxman \& Kilcoyne 1993). In other words, the individual's knowledge of information about himself will to a large extent influence the decision to control the way and manner such information is used. This philosophical idea of information privacy i.e. control and knowledge, was reflected in a speech by the former vice president of United States to graduating students at New York. In his speech, Albert Arnold Gore, Jr. stated that '...you should have the right to choose whether your personal information is disclosed, you have the right to know how, when and how much of that information is being used, and you should have the right to see it yourself, to know if it's accurate' (cited in Adams \& Martz, 1999 p. 1381). This means that consumers should know why their details are being collected and for what purpose, and should be able to control how their details are being used (Smith et al., 1996).

Consequently, business organisations are charged to apply the principles of notice, access, choice, data security and enforcement (see Pollach, 2005). In other words, businesses should tell consumers why their details are collected, and consumers should have access to their information and what it is being used for. The consumers should also be given the choice to protect his/her data, and businesses should protect consumer data from unauthorised access. In addition, businesses should enforce the decisions of the consumer. Collier (1995) holds a similar position to this. He stated that business organisations should meet vital standards like openness, awareness, consent, use, disclosure and security. By keeping these standards, consumers will have sufficient knowledge of what businesses do with their details and control such usage. This will to a large extent influence their attitudes towards information privacy and data collection by businesses. According to Culnan (1995), the more people are aware of what their details are being used for, the greater will be their positive attitude towards information privacy and data collection mechanism by business organisations. Nowak and Phelps (1995) also added that when consumers have knowledge of the data collection processes of business organisations, what such information are used for, and their ability to control usage of such information, the consumers are less likely to worry about information privacy. This is because the issue of information privacy mostly arises when the consumers have no knowledge of what their details are used for and are unable to control data usage by businesses (Graeff \& Harmon, 2002).

Therefore, this paper shall approach information privacy from the ideas of control and knowledge, as both factors i.e. the ability of consumers to control the use of their personal information by business and having knowledge of what their personal information is used for will influence their attitude and perception towards the usage of loyalty cards. To this end, I shall adopt Phelps' et al. (2000 p. 29) position which considers information privacy as 'the ability to affect the dissemination and use of personal information that is collected during or as a result of marketing transactions, as well as control over unwanted telephone, mail or personal intrusions in the consumer's home'.

\section{Loyalty Cards and Information Privacy}

Most studies on the use of loyalty cards and privacy concerns are mainly from the American and European perspectives (Hine, 1998). Little or no literature have examined loyalty cards and information privacy from the South African perspective especially with regard to Generation $Y$ students. This paper shall therefore draw from the extensive Western literature on loyalty cards and contextualise it with the South African experience.

In this information driven economy, most business organisations have started creating 'gigantic databases' that have the capability to collect and store individuals information like 'gender, income, hobbies and purchases' (Solove, 2001 p. 1395). One way through which such information is collected from individuals and stored in the business database is through loyalty cards. Loyalty cards go by different names from store to store; like reward card, discount card, frequent shopper card, smart shopper cards, club card etc. These thin plastic cards with similar appearance to bank cards (Hine, 1998), have in the last two decades been widely defused into the business world. For instance in a poll conducted in the United Kingdom in 2002, more than half of the United Kingdom adults claim to have and use loyalty cards (Smith, 2004). Similarly, studies conducted in the United States reveal that $42 \%$ of shoppers prefer using loyalty cards when shopping (ibid). Solove (2001) also argued that our wallets are filled with loyalty cards from different stores. 
The principal reason for the increasing use of loyal cards by businesses is to foster and develop consumerbusiness relationship with the motive of enhancing business growth. As Meyer-Waarden describes 'loyalty cards represent tools for developing relationship and sow, offer integrated systems of marketing actions and economic, psychological, and sociological rewards. Successful loyalty schemes increase customer retention, lifetime duration and customer sow' (2007 p. 224). The above quote elucidates the central objective of loyalty card schemes in business. In a competitive business environment (Argandona, 2003), marketers and retailers are striving to retain customers and prevent them from patronising multiple outlets, thus loyalty cards have become a fundamental strategy to secure 'a greater part of consumer expenditure' (Meyer-Waarden, 2007 p. 223).

In order for consumers to be better served by businesses, loyalty cards are issued to them after a short form requesting for their details have been completed (Solove, 2001). This according to Graeff and Harmon (2002) is an indirect way for the business organisations (retailers, marketers) to collect sensitive information about consumers under the pretence of providing valuable services like bonuses and rewards. Hence the use of loyalty cards by consumers gives business organisations the opportunity to track their purchasing and other transactions (Hine, 1998). Simms (2007 p. 24) posited that the use of the loyalty cards enable businesses to 'keep track of exactly everything a cardholder has ever bought, from which store and the precise date and time of each purchase'. Recording such details will allow the businesses to monitor consumers shopping pattern, and 'from that build up a profile of what sort of shopper they are' (Smith, 2004 p. 51). Consequently, vouchers and shopping catalogues are designed to reflect the preferences and needs of each individual shopper. Phelps et al., while buttressing the above fact argued that 'most marketers have used consumer information to guide their marketing and promotion efforts for decades, however, the information and databases they have relied on typically have been market-level information or modelled data which is consumer information that reflects the generalised characteristics of a consumer group, market segment, media audience or geographic region' (2000 p. 28). Hence, Zurawski sees the loyalty card as 'an interface between everyday practices and an economy of personal information with its data flows and monitoring strategies' (2011 p.516).

Although, these businesses might argue that such targeted vouchers or catalogues are designed to save consumers money when shopping ${ }^{3}$, research has however, suggested otherwise. According to Smith (2004), retailers and marketers want their consumers to think that the discount voucher or bonuses from the loyalty cards saves them money, but in actual fact it encourages them to buy more products which they actually do not need. Thus the rationale for the adoption of loyalty cards by businesses is to increase sales (Shepherdson, 2000). Similarly, Taylor and Neslin (2005) in their study argued that loyalty cards increases sales in two ways namely, point pressure and reward behaviour; 'the point pressure mechanism is the short-term impact whereby clients increase their purchase rate to earn rewards, whereas the reward behaviour mechanism is the long-term impact, whereby clients increase their purchase rate after they have received the reward' (cited in Meyer-Waarden, 2007 p. 224).

This process of monitoring consumers' purchases and targeting them with sales and promotional offers through the loyalty card scheme has raised serious fundamental issues with regards to data collections and usage by businesses. Issues such as whether it is ethical for businesses to collect and store consumers' data, if the use of such data for developing consumers' preferences and targeting them with promotional offers does not violate their privacy, and how businesses can balance the act of data collecting through loyalty cards and protecting the privacy of the consumers. Numerous research and surveys conducted in the past reveal that consumers are worried about the degree of information and extent to which retailers and marketers know them, and how the data collected from them are used (Phelps, et al., 2000). While retailers and marketers may claim that data collected from consumers are protected from unauthorised persons and not used in a way that will harm the consumers (Collier, 1995), consumers are increasingly concerned about their information privacy (Graeff \& Harmon, 2002) since they have no control over how such data is used.

This increasing concern on the part of the consumer has led to the belief that retailers and marketers do not consider the privacy of their consumers in their activities, and this could affect the attitude of the consumers towards the use of loyalty cards (Graeff \& Harmon, 2002). Although, some studies on loyalty cards ${ }^{4}$ and perception suggest that consumers have positive perception towards loyalty cards, still, concerns are expressed over information privacy (ibid), and this affects consumer attitude towards the usage of loyalty cards. Therefore, as previously stated, the ability of consumers to control the usage of their information by business and their knowledge of what is done with their

\footnotetext{
${ }^{3}$ Most retailers or stores that make use of loyalty cards believe that the central objective of the loyalty card scheme is to save consumers some money, as they save points on every purchase which the consumers can in the future use to buy good. The idea is the more the consumer buys, the more he/she saves.
}

${ }^{4}$ See Lewis, 2004; Nako, 1997; and Kivetz et al., 2006. 
information will significantly influence their attitude and perception towards information privacy in relation to loyalty cards. On the other hand, Foxman and Kilcoyne (1993) argued that consumers' attitude and perception towards information privacy is determined by socio-economic and cultural factors. In this study, it will be determined whether the attitudes of Black Generation Y students towards information privacy with regard to the use of loyalty cards is influenced by their ability to control their data and knowledge of how their data is used.

\section{Black Generation Y students' Attitude towards Loyalty Cards: Hypothesis}

Scholars conceptualise Generation $Y^{5}$ students differently. Some tend to conceptualise Generation $Y$ based on era of technological advancement (see Nimon, 2007). Proponents of this position argue that the arrival of the Generation $Y$ coincide with development of information technologies like world wide web (www), mobile phones and instance communication and messaging (Nimon, 2007). Skiba (2005) therefore posits that in the conceptualisation of Generation $\mathrm{Y}$, there is the need to understand the connection, relationship and behaviour of those born during the emergence of technological advancement with their usage of such technologies. This is because these technologies 'have been transformed from the simple tools of the baby boomer into devices through which they experience and interact with their world' (Nimon, 2007 p.27).

On the other hand, Weiler (2005) follows the age determinant in conceptualising Generation Y students. According to her, 'Generation $Y$ is the generation that is born between 1980 and 1994. They are students currently on college campuses, as well as those due to arrive in the next few years' (ibid p. 46). However, there is debate on the precise year of birth that Generation $Y$ includes. While some state that it includes those born from 1980, others argue that it should be those born from 1982 (see Huntley, 2006). For this study, I shall define Generation Y students as those born from 1986 that are in tertiary institutions (in-line with Weiler's (2005) position) with the potential of earning high income.

Following the end of apartheid in 1994, significant changes have occurred in South Africa (see Venter, 2010). These changes facilitated by political liberation and economic emancipation have created opportunities for exploration of Black Generation Y students in the marketing industry. The black Generation Y students which represent about 84\% of the Generation Y group (see Statistics of South Africa, 2012), with potential of high income earnings (Plessis et al., 2009) have not only created a new market for businesses but are being exploited. Seeing that they are younger and represent the middle class group in society (Venter, 2010), and will later become the black diamond with a buying power of approximately R200 billion (Anon, 2008) they are targeted by business organisations (Youn, 2009). Their age and inexperience also makes them vulnerable to the practice of collecting personal data for marketing and promotional purposes by businesses. Huntley (2006) believes that unlike the older generation, Generation Y students are not concerned with information privacy because their lives have been exposed to such much marketing activities from businesses (Nimon, 2007). Huntley's study was however conducted in Australia, so it is important to examine the attitude of Black Generation $Y$ students to information privacy from the South African perspective. Are they concerned about information privacy? Do their concerns influence their attitude towards loyalty cards in relation to information privacy? The following hypotheses will help address the research questions stated in the introductory section:

$>$ The ability of Black South African Generation Y Students to control the use of personal data by stores will lead to a positive attitude towards information privacy.

> Prior knowledge about information privacy by Black South African Generation Y students will lead to a positive attitude towards information privacy in loyalty card programmes.

> The inability of Black South African Generation Y Students to control the use of personal data by store(s) will lead to a negative attitude towards information privacy.

$>$ Lack of prior knowledge about information privacy by Black South African Generation Y Students will lead to a negative attitude towards information privacy in loyalty card programmes.

These hypotheses take into account the fact that it is impossible to live a private and solitary life in this global economy characterised by the information communication technologies. It seeks to answer the question of how information privacy can be managed or controlled in the $21^{\text {st }}$ century business world characterised by the massive usage of information gathering techniques like loyalty card (Argandona, 2003).

\section{Methodology}

5 There have been numerous debates about Generation Y. Apart from the debate on how Generation Y should be conceptualised, there is also the issue of what they should be called. Sometimes Generation Y are referred to Generation X2, Echo Boom etc. see Nimon, 2007; Howe and Strauss, 2000. 
Data was collected from a written questionnaire that was administered to 400 anonymous students at two different Universities i.e. North West University (Vaal Triangle Campus), and Vaal University of Technology in South Africa using the convenient sampling method. These Universities represent two main types of Universities in South Africa that is the traditional university which offers theoretical oriented education, and the University of Technology which offers vocational oriented education. These Universities are located in the Gauteng province of South Africa which is regarded as the hub for Black Generation Y students in South Africa, since majority of Black Generation Y students study in the Gauteng (Bevan-Dye \& Surujlal, 2011). Therefore, findings from this study should give a clear representation of the attitude and perception of Black Generation Y students towards information privacy and loyalty cards.

The questionnaire was divided into three sections A, B and C. Section A covers demographic information about the students and information to test the knowledge of the students about information privacy and loyalty cards. Section B covers questions to ascertain the attitude and perception of Black Generation Y students with regard to control of personal information and knowledge of what such information is used for by business organisations using the loyalty cards. The questions were designed using the five (5) points Likert Scale ranging from strongly disagree to strongly agree. Section $\mathrm{C}$ contains open ended questions designed to test the accuracy and constituency of the student's knowledge of information privacy while filling the questionnaires. Students were asked to give instances of when they think stores might have used their data stored in loyalty cards in a way that violated their privacy. They were also to give examples of information they believe stores should protect and/or seek their approval first before using them for promotional and marketing purposes.

A pilot test was conducted using 30 students at Computer Training Institute (CTI) Education Group, Vanderbiljpark to test their knowledge of information privacy with regard to loyalty cards. This to an extent influenced the administration of the questionnaire to the students at the different Universities. The filling of the questionnaires was voluntary and lecturers at the Universities helped in administering and collecting the completed questionnaires from students in their respective classes.

\section{Findings and Discussion}

\subsection{Response Rate and Respondent Profile}

A total of 400 questionnaires were administered at both Universities, however a total of 283 questionnaires were returned (completed). The response rate from North West University (NWU) and Vaal University of Technology (VUT) was 40.3\% and 59.7 respectively (see Table 1 for summary).

Table 1. Response Rate of Institutions

\begin{tabular}{cccc}
\hline Institution & Frequency & Percent & Valid Percent \\
\hline NWU & 114 & 40.3 & 40.3 \\
VUT & 169 & 59.7 & 59.7 \\
Total & 283 & 100.0 & 100.0 \\
\hline
\end{tabular}

Of the total respondents $41.0 \%$ were males and $59.0 \%$ were females. For age demographics, respondents aged between 18-21, $22-24$ and 25 years and over represented $62.9 \%, 30.4 \%$ and $5.3 \%$ respectively. $84.8 \%$ of the total respondents where undergraduates undertaking a degree course at the Universities, $9.9 \%$ were Honours students, $0.7 \%$ were pursuing a Master's degree and $0.4 \%$ were Doctoral (Doctor of Philosophy (Ph.D)) students. In addition, 49.8\% of the respondents had a monthly income of less than R1000, 26.5\% had an income of R1001-R2000, 7.1\% had an income of R2001-R3000, and 4.9\% had an income above R3000. A total of $11.7 \%$ did not disclose their financial status. A total of $91.5 \%$ of the respondents were single, $1.8 \%$ were married and $6.4 \% \%$ were in a partnership relationship. $0.4 \%$ of the respondents did not disclose their marital/relationship status.

\subsection{Loyalty Card Possession and Usage}

When asked on the number of royalty cards the respondents possessed and the main reason(s) for signing up or not signing up for a loyalty card, $39.9 \%$ of the respondents did not have a loyalty card, $20.5 \%$ had 1 loyalty card, $22.6 \%$ had 2 cards, $11.3 \%$ had 3 loyalty cards, $1.8 \%$ had 4 loyalty cards, $0.7 \%$ had 5 cards, $1.1 \%$ had 6 or more loyalty cards. $2.1 \%$ of the respondents did not disclose whether or not they had a loyalty card. 
Most of the respondents with loyalty cards had cards mostly from shops like: Picknpay, Marko, Edgers, Woolworths, Mr Price, Identity, Clicks amongst others. Clicks had the highest percentage of $41.0 \%$, followed by Pick'npay of $31.1 \%$, and Edgars had $7.4 \%$. Most of the respondents had Clicks 'Club Card' probably because they were the first business organisation to introduce and start the loyalty card scheme in 1996 (see www.clicks.co.za). They also sell a wide range of products, ranging from electrical appliances, baby items, pharmacy, etc. Picknpay was the second most popular loyal card and is known for selling food commodities, household items etc. while Edgar is a clothing shop. The fact that these 3 business organisations provide goods or services that are needed on the daily basis may account for the high ownership of their loyalty cards amongst the respondents.

However, the percentage of those who did not possess a loyalty card was high, i.e. $39.9 \% .14 .8 \%$ of these respondents attributed their inability or unwillingness to have loyalty cards to the card signing up process, which they considered a waste of time. $5.7 \%$ of the respondents had not signed up for a loyalty card mainly because of security reasons. They did not want their activities being monitored or unauthorised person(s) accessing their personal data. Another, $5.7 \%$ had not signed up for a loyalty card because they believed there are no benefits associated with loyalty cards. To them, loyalty cards were a plot by business organisations to make consumers buy more goods. $4.6 \%$ of the respondents who had not signed up for loyalty cards were indifferent towards the scheme, while $2.1 \%$ were concerned about data protection as they were unwilling to release sensitive information to business organisations in order to obtain loyalty cards.

On the other hand, respondents that had signed up for the loyalty cards also had different reasons for doing so. $42.0 \%$ signed up because of bonuses and points which can be used in stores. $9.2 \%$ of the respondents signed up because of the deals and offers they are likely to get from the usage of the loyalty card, while $4.9 \%$ signed up because they believed that the store/business organisation are trustworthy (i.e. do not engage in questionable or unethical business transactions) and so will be able to properly manage their personal data. In addition, $14.5 \%$ of the respondents signed up for the loyalty card purely because it is part of their shopping habits. $8.1 \%$ of the respondents signed up because they thought it was fun.

When asked how often they swiped their loyalty cards when shopping, $30.0 \%$ of the respondents had never used or swiped their cards after a purchase, $14.5 \%$ said they rarely swiped their cards after a purchase, $23.3 \%$ sometimes swiped their cards after purchase, $16.3 \%$ frequently swiped their cards, and $8.5 \%$ usually swiped their cards after every purchase. $7.4 \%$ of the respondents did not complete this question. One question is clear from the above statistics, i.e. why $30 \%$ of the respondents who had signed up for a loyalty card never swiped nor used them. It can be speculated that most of them were pressurised or persuaded to sign up for the cards at the shops but never used the cards afterwards probably because they were concerned about the privacy issues surrounding loyalty card usage. The fact that the signing up process is free could also be a factor.

\subsection{Knowledge of Information Privacy}

To ascertain whether the respondents understood the study and how that will influence their completion of the questionnaire, they were asked to indicate their level of knowledge of information privacy. $7.8 \%$ of the respondents had poor knowledge of information privacy, $27.6 \%, 34.3 \%, 14.8 \%, 8.1 \%$ had fair, good, very good and excellent knowledge of information privacy respectively. $7.4 \%$ of the respondents did not complete this question. The above statistics show that a significant number of the respondents had a good knowledge of what the research was about; this to a large extent will influence the findings of the study (see Table 2 and Table 3 below).

\subsection{Reliability}

In order to assess reliability, internal consistency of measurement was computed for the entire scale and individual subdimensions of the scales. The standardised Cronbach alpha value for the instrument was 0.649 indicating that the scale items performed adequately in reflecting the elements of loyalty cards in relation to information privacy. The Cronbach alpha values for all two variables ranged from 0.599 to 0.654 which is below the benchmark of 0.70 suggested by Nunnally \& Berstein (1994), therefore indicating satisfactory reliability of the scale variables. The results are reported in Table 2 and Table 3 below. 
Table 2. Reliability Statistics

\begin{tabular}{ccc}
\hline Cronbach's Alpha & Cronbach's Alpha Based on Standardized Items & N of Items \\
\hline .634 & .649 & 20 \\
\hline
\end{tabular}

Table 3. Reliability and item-to-total correlations extracted for the scale

\begin{tabular}{|c|c|c|c|}
\hline $\begin{array}{l}\text { Loyalty } \\
\text { card }\end{array}$ & Scale Items & $\begin{array}{c}\text { Corrected Item } \\
\text { Total Correlations }\end{array}$ & $\begin{array}{l}\text { Reliability } \\
\text { (a) }\end{array}$ \\
\hline \multirow[t]{15}{*}{ Control } & $\begin{array}{l}\text { I am concerned that my purchases at stores can be tracked and } \\
\text { used for other promotional offers. }\end{array}$ & .210 & .624 \\
\hline & $\begin{array}{l}\text { I am comfortable with the recording of my purchases using loyalty } \\
\text { card. }\end{array}$ & .076 & 639 \\
\hline & $\begin{array}{l}\text { I trust the stores with the way they use my data stored in the loyalty } \\
\text { card. }\end{array}$ & .300 & .613 \\
\hline & $\begin{array}{l}\text { I am concerned about the way the data stored through loyalty cards } \\
\text { programs might be used. }\end{array}$ & .228 & .622 \\
\hline & $\begin{array}{l}\text { I can control the way stores use the data collected in the loyalty card } \\
\text { program. }\end{array}$ & .268 & 617 \\
\hline & $\begin{array}{l}\text { I receive promotional offers from stores encouraging me to use my } \\
\text { loyalty cards. }\end{array}$ & .407 & .599 \\
\hline & I like to receive promotional offers through catalogues. & .128 & .637 \\
\hline & I ignore promotional offers. & .102 & 639 \\
\hline & It annoys me that I receive unsolicited catalogues & .169 & 629 \\
\hline & $\begin{array}{l}\text { I am concerned about threats to my information privacy from such } \\
\text { promotional offers through catalogues. }\end{array}$ & .327 & .610 \\
\hline & I have lost control over how my personal information is used. & -.032 & .654 \\
\hline & $\begin{array}{l}\text { Stores should not use personal information for any other purposes } \\
\text { other than the one authorised by me. }\end{array}$ & .371 & .606 \\
\hline & $\begin{array}{l}\text { Stores should always seek my permission before using my personal } \\
\text { information for promotional and marketing purposes. }\end{array}$ & .361 & .608 \\
\hline & $\begin{array}{l}\text { The information available to me when signing for the loyalty card was } \\
\text { adequate. }\end{array}$ & .133 & .633 \\
\hline & When signing for the loyalty card, I was aware of information privacy. & .216 & 623 \\
\hline \multirow[t]{5}{*}{ Knowledge } & $\begin{array}{l}\text { My knowledge of information privacy influences my approach or use } \\
\text { of loyalty card. }\end{array}$ & .396 & .601 \\
\hline & $\begin{array}{l}\text { I know what the personal data collected from me through the loyalty } \\
\text { card is used for. }\end{array}$ & .142 & 632 \\
\hline & I am worried with the data trade connected with my loyalty card. & .295 & 614 \\
\hline & $\begin{array}{l}\text { When I receive mail offers I don't want, I am aware of procedures } \\
\text { that allow me to opt out. }\end{array}$ & .212 & .624 \\
\hline & I am presented with the choice of opting out of loyalty card program. & .313 & .612 \\
\hline
\end{tabular}

Overall Cronbach alpha for the scale $=0.649$

\subsection{Correlation Analysis}

The Pearson Correlation Coefficient ( $r$ ) was used to analyse the inter-factor association between the two variables i.e. (Control, and knowledge) with a view to establishing the direction and strength of the relationships towards information privacy. For this study, values near -1 and 1 indicate strong negative and positive correlation respectively, values near zero $(0)$ indicate weak correlation, while a value of +1 or -1 indicate a perfect relationship.

\subsection{Analysing the Hypotheses}

\subsubsection{Hypothesis 1}

It was predicted that the ability of Black South African Generation Y Students to control the use of personal data by stores will lead to a positive attitude towards information privacy. Only $20.6 \%$ of the respondents believed that they could control 
the way stores used their personal data through the loyalty card scheme. Pearson correlation analysis showed a strong positive relationship between unsolicited catalogues received and the tendency to ignore such promotional offers through the catalogues $\left(r=.528^{\star *} ; p=.000\right)$. This suggests that Generation $Y$ students want to control the way their personal data are used for promotional purposes through the loyalty card scheme. They also want business organisations to seek their permission before their data is been used for other purposes. There is also a weak positive relationship between loss of control of personal data usage and irritation by unwanted marketing $\left(r=.203^{* *} p=.002\right)$. This is an indication that Generation Y students get irritated or annoyed by unsolicited marketing offers or catalogues as they feel they have no control of how their personal data is used. Although, it was stated in a previous study, that Generation $Y$ students are not concerned with information privacy since their lives have been built around marketing activities (Nimon 2007), the observations from this study contradicts this position. They are nonetheless, in line with those of the study of Foxman and Kilcoyne (1993), where it was concluded that the ability of consumers to control their personal information will lead to a positive attitude towards information privacy. This is further buttressed by the fact that $30 \%$ of the respondents who signed up for loyalty cards never used them. It can be inferred that their desire to be in control of their personal information may contribute to their decision not to use the cards.

\subsubsection{Hypothesis 2}

It was predicted that having prior knowledge or knowledge of information privacy will lead to a positive attitude towards information privacy in loyalty card programs among Black South African Generation Y students. This hypothesis is supported by the data, as there is a moderate positive relationship between having prior knowledge of information privacy and positive attitude to loyalty card usage $\left(r=.359^{\star *} ; p=.000\right)$. The respondents' knowledge of information privacy to a large extent influenced their positive perception towards loyalty card. There was also a positive correlation between respondents' knowledge of information privacy and their willingness to allow recording of their purchases through the use of loyalty cards $\left(r=.359^{* *} ; p=.000\right)$. Nevertheless, the respondents expressed some concerns over the data trade that is associated with such storage, as there was a weak positive correlation between respondents' knowledge of information privacy and concerns that their purchases can be tracked through loyalty cards $\left(r=.212^{* *} ; p=.001\right)$.

\subsubsection{Hypothesis 3 and 4}

It was predicted that lack of knowledge of information privacy and the inability of Black South African Generation $Y$ Students to control the use of personal data by stores will lead to a negative attitude towards loyalty card usage. As indicted in hypothesis 1 and 2, positive perception or attitude is developed by Black Generation Y students when they have knowledge of what information privacy is and are able to control their personal data usage, i.e. how their data is being used. In the same way, it can be assumed that lack of knowledge of information privacy and inability to control personal data usage in loyalty cards will lead to a negative perception. However, there was no or negligible correlation between ignorance about information privacy and the desire to control personal data usage ( $r=.076 ; p=.237)$. That is respondent's ignorance on what information privacy was had little or no effect on their desire to control personal data usage when using loyalty cards.

\section{Limitation of Study}

A limitation of this study is that the study was conducted in just 2 Universities i.e. a traditional university and a technical university in South Africa. The study was originally designed to cover the 3 types of universities in South Africa (traditional, technical and comprehensive). However, the authorities of the comprehensive university approached for this study declined the researcher from administering the questionnaires to students. There was time constraint to make further applications to other comprehensive universities, and so the study was limited to these 2 Universities. In addition, this study focused on a single ethnic group (Black Generation $Y$ students). Further research is needed in order to ascertain if the findings of this study applies to other ethnic groups in South Africa.

\section{Conclusion}

This study set out to investigate the attitude and perception of Black Generation Y Students towards information privacy and loyalty card usage. Findings from the study established that Black Generation Y students have information privacy 
concerns with regard to the use of loyalty cards. Also Generation $Y$ students were irritated or annoyed by unsolicited marketing offers or catalogues as they feel they have no control of how their personal data is used. In the same way respondents without knowledge of information privacy had little or no desire to control how their data is being used. Consequently, respondents' knowledge of what information privacy is, and their ability to control their personal data usage by business organisations, will lead to a positive attitude or perception towards information privacy in relation to loyalty card usage.

\section{References}

Adam, L. \& Martz, D. (1999). Developments in Stored-Value Cards and Cyberbanking. The Business Lawyer, 54(3), 1373-1387.

Argandona, A. (2003) The New Economy: Ethical Issues. Journal of Business Ethics, 44(1), 3-22.

Bevan-Dye, A. \& Surujlal, J. (2011). Attitude towards Materialism in Sport and Materialism Tendencies amongst Black Generation Y Students. African Journal for Physical, Health Education, Recreation and Dance, Supplement 1, 43-55.

Collier, G. (1995). Information Privacy. Information Management and Computer Security, 3(1), 41-45.

Culnan, M. (1993). How did they get my name? An Exploratory Investigation of Consumer Attitudes Towards Secondary Information Use. MIS Quarterly, 17(3), 341-363.

Culnan, M. \& Armstrong, P. (1999). Information Privacy Concerns, Procedural Fairness and Impersonal Trust: An Empirical Investigation. Organisation Science, 10(1) 104-115.

Dinev, T. \& Hart, P. (2006). Privacy Concerns and Levels of Information Exchange An Empirical Investigation of Intended E-Service Use. E-Service Journal, 4(3), 25-60.

Dinev, T. \& Hart, P. (2006a). Internet Privacy Concerns and Social Awareness as Determinants of Intention to Transact. International Journal of Electronic Commerce, 10(2), 7-29.

Foxman, E. \& Kilcoyne, P. (1993). Information Technology, Marketing Practice, and Consumer Privacy: Ethical Issues. Journal of Public Policy and Marketing, 12(1), 106-119.

Goodwin, C. (1991). Privacy: Recognition of a Consumer Right. Journal of Public Policy and Marketing, 10 (1), 149-166.

Graeff, T. \& Harmon, S. (2002). Collecting and Using Personal Data: Consumers' Awareness and Concerns. Journal of Consumer Marketing, 19(4), 302-318.

Hine, C. (1998). Privacy in the Marketplace. The Information Society: An International Journal, 14(4), 253-262.

Huntley, R. (2006). The World According to Y: Inside the New Adult Generation. Australia: Allen \& Unwin.

Introna, L. \& Pouloudi, A. (1999). Privacy in the Information Age: Stakeholders, Interests and Values. Journal of Business Ethics, 22(1), 27-38.

Jarvenpaa, S. \& Staples, S. (2001). Exploring Perceptions of Organisational Ownership of Information and Expertise. Journal of Management Information Systems, 18(1), 151-183.

Meyer-Waarden, L. (2007). The Effects of Loyalty Programs on Customer Lifetime duration and Share of Wallet. Journal of Retailing, 83(2), 223-236.

Milne, G. \& Gordon, M. (1993). Direct Mail Privacy-Efficiency Trade-Offs Within anImplied Social Contract Framework. Journal of Public Policy and Marketing, 12(2), 206-215.

Miyazaki, A. \& Fernandez, A. (2000). Internet Privacy and Security: An Examination of Online Retailer Disclosures. Journal of Public Policy and Marketing, 19(1),54-61.

Nimon, S. (2007). Generation Y and the Higher Education: The Other Y2K. Journal of Institutional Research, 13(1), 24-41.

Nunnally, J. \& Bernstein, I. (1994). Psychometric Theory. (3rd ed). New York: McGraw-Hill.

Phelps, J.; Nowak, G. \& Ferrell, E. (2000). Privacy Concerns and Consumer Willingness to Provide Personal Information. Journal of Public Policy and Marketing,19(1), 27-41.

Plessis, L.; Berndt, A. \& Petzer, D. (2009). The Attitude of Generation Y Students at a South African University Towards Supporting Charitable Organisations. Global Business and Technology Association, 1-11.

Pollach, I. (2005). A Typology of Communication Strategies in Online Privacy Policies: Ethics, Power and Informed Consent. Journal of Business Ethics, 62(3), 221-235.

Pretschner, A.; Hilty, M. \& Basin, D. (2006). Distributed Usage Control. Communications of the ACM, 49(9), 39-44.

Rule, J. (2004). Toward Strong Privacy: Values, Markets, Mechanisms, and Institutions. The University of Toronto Law Journal, 54(2), 183-225.

Shepherdson, N. (2000). Holding All The Cards Grocers want Frequent-Shopper Programs to get up Closer and Very Personal. American Demographics, 35-37.

Simitis, S. (1987). Reviewing Privacy in an Information Society. University of Pennsylvania Law Review, 135(3), 707-746.

Simms, A. "Getting to Know You", New Stateman, June 25.

Smith, J. (2004). Every Little Helps. The Ecologist,

Smith, J.; Milberg, S. \& Burke, S. (1996). Information Privacy: Measuring Individuals' Concerns about Organisational Practices, MIS Quarterly, 20(2), 167-196.

Solove, D. (2001). Privacy and Power: Computer Databases and Metaphors for Information Privacy. Stanford Law Review, 53(6), 13931462. 
Staten, M. \& Cate, F. (2003). The Impact of Opt-in Privacy Rules on Retailer Credit Markets: A Case Study of MBNA. Duke Law Journal, 52(4),745-786.

Statistic South Africa (2012).Mid-year Population Estimate 2011. Pretoria: Stats SA.

Tavavi, H. (2007). Philosophical Theories of Privacy: Implications for an Adequate Online Privacy Policy. Metaphilosophy, 1-22.

Venter, R. (2010). The Evaluation of Service Delivery in the Fast Growing Black Diamond Market. North West University, Masters Dissertation.

Weiler, A. (2005). Information-Seeking Behaviour in Generation Y Students: Motivation, Critical Thinking and Learning Theory. The Journal of Academic Librarianship, 31(1), 46-53.

Youn, S. (2009). Determinants of Online Privacy Concern and Its Influence on Privacy Protection Behaviours Among Young Adolescents. The Journal of Consumer Affairs, 43(3), 389-418.

Zurawski, N. (2011). Local Practice and Global Data: Loyalty Cards, Social Practices and Consumer Surveillance. The Sociological Quarterly, 52, 509-527. 